\title{
Imbricate thrust stack model for the formation of glaciotectonic rafts: an example from the Middle Pleistocene of north Norfolk, UK
}

\author{
HELEN BURKE, EMRYS PHILLIPS, JONATHAN R. LEE AND IAN P. \\ WILKINSON
}

\author{
Burke, H., Phillips, E., Lee, J.R. \& Wilkinson, L.A. XXXX. Imbricate thrust stack \\ model for the formation of glaciotectonic rafts: an example from the Middle \\ Pleistocene of north Norfolk, UK. Boreas, Vol. XX, pp. xxx-xxx.
}

This paper presents a glaciotectonic model for raft emplacement based upon a study of large- and small-scale deformation structures associated with the accretion of chalk rafts at three Middle Pleistocene sites on the north Norfolk coast, eastern England. Detailed structural measurements taken from the three localities indicate an overall sense of ice movement and raft emplacement towards the south/south-east, suggesting a source area for the rafts located to the north of the present Norfolk coast in the offshore area of the North Sea. Provenancing of the chalk rafts, based on analysis of the foraminifera, also indicates a northern near-shore provenance for the chalk. Mechanisms for the detachment, transport and accretion of the rafts are explored, and it is concluded that pressurised pore water played an important role in all three phases. An imbricate thrust stack model of glaciotectonic raft generation is presented, with the structural history of raft emplacement explained by the geometric relationships between the large-scale basal shear planes and associated deformation structures within adjacent preglacial and glacial sediments.

Helen Burke (e-mail: hkb@bgs.ac.uk), Jonathan R. Lee, Ian P. Wilkinson, British Geological Survey, Keyworth, Nottingham, NG12 5GG, UK. Emrys Phillips, British Geological Survey, Murchison House, West Mains Road, Edinburgh, EH9 3LA, UK.

Glacial rafts, 'floes' or 'megablocks' are defined as dislocated slabs of bedrock and/or unconsolidated sedimentary strata that have been transported from their original position by glacial action (Stalker 1976; Christiansen \& Whitaker 1976; Aber 1985, 1988; Ruszczynska-Szenajch 1987; Broster \& Seaman 1991; Benn \& Evans 1998). Such rafts are typically composed of relatively thin slabs of material that may have been transported over distances ranging from tens of metres to hundreds of kilometres. They generally occur as single, horizontal slab-like features, but may be stacked within conspicuous ice-pushed hills of various types (Banham 1975; Aber 1988; Benn \& Evans 1998). Internally, rafts frequently appear undeformed, although at a larger scale they may form parts of large nappe-like fold structures, be cut by shear zones, faults and brecciated/cataclastic zones.

Several models have been proposed to explain the generation of glacial rafts. Banham (1975) and Aber (1988) have suggested that the principal mechanism of raft 
detachment and transportation is associated with the freezing of the substrate to the underside of cold-based glacier ice. Alternatively, other studies have suggested that failure, leading to detachment, is associated with elevated pore water pressures. Such occurrences may develop along water-rich décollement surfaces within the subglacially deforming layer (Moran et al. 1980; Broster \& Seaman 1991; Benn \& Evans 1998; Phillips \& Merritt 2008); at the base of the deforming layer (Kjær et al. 2006); or as a consequence of subglacial hydrofracturing by forceful upward dewatering (Boulton \& Caban 1995; Rijsdijk et al. 1999). Rafts have also been shown to be generated as a result of thrusting associated with proglacial compressive deformation, with these glaciotectonic rafts occurring within an imbricate thrust stack (push moraine), forming in front of the advancing glacier (Banham 1975; Christiansen \& Whitaker 1976; Moran et al. 1980; Bluemle \& Clayton 1984; Ruszczynska-Szenajch 1987). Phillips \& Merritt (2008) have invoked a purely glaciotectonic model to explain the detachment, transport and accretion of ice-rafted, shelly marine sediments in NE Scotland. These authors argue that the transport and preservation of the soft-sediment slabs was aided by the presence of water lubricated décollement surfaces within the deforming sedimentary pile.

Although the presence of large (tens of metres in length) chalk rafts have long been recognised within the Middle Pleistocene glaciogenic sediments of northeast Norfolk, their origin and the nature of the processes involved in their detachment, transportation and accretion remains poorly understood. This paper presents results of a detailed palaeontological study, and macroscopic structural study of the chalk rafts and associated glaciotectonic structures from three localities on the northeast Norfolk coast in eastern England (Fig. 1) and a structural model for their generation.

\section{Location of study area and geological context}

The geology of northeast Norfolk comprises Upper Cretaceous chalk bedrock overlain by a veneer of Quaternary sediments (Moorlock et al. 2002). The chalk bedrock belongs to the White Chalk Subgroup of the Chalk Group and dips gently (< $1^{\circ}$ ) eastwards, exposing successively younger chalk strata from west to east across the area (Fig. 1), ranging from Upper Campanian to Maastrichtian in age. Resting unconformably upon the upper surface of the chalk are shallow marine sands and gravels of the Wroxham Crag Formation (WCF) that have been attributed to an Early to early Middle Pleistocene age (Briant et al. 1999; Rose et al. 2001; Pawley et al. 2004). These are in turn overlain by a thick glaciogenic sequence, comprising tills, lacustrine and outwash deposits (Banham 1968; Hart \& Boulton 1991a; Lunkka 1994; Lee et al. 2004) - including the Happisburgh Till Member (HTM), Walcott Till Member (WTM) and Bacton Green Till Member (BTM). Previously these tills have been termed the North Sea Drift (Cromer Tills), and widely attributed to the presence of Scandinavian ice in eastern England during the Middle Pleistocene Anglian Glaciation (Perrin et al. 1979; Bowen et al. 1986; Ehlers \& Gibbard 1991).

Three rafting sites along the north Norfolk coast have been examined in this study - Overstrand (National Grid Reference (NGR): TG 256 405), East Runton 
(NGR: TG 197 428) and West Runton (NGR: TG 174 433). These sites lie within an area where the term 'Contorted Drift' has been applied, due to the highly disturbed nature of the stratigraphic succession (Banham 1968, 1975, 1988). Elements of this disturbance relate to soft-sediment deformation and mixing during subglacial deformation (Banham 1977; Hart \& Boulton 1991b; Roberts \& Hart 2005; Lee \& Phillips 2008; Phillips et al., 2008) and proglacial thrusting associated with the formation of the Cromer Ridge push moraine complex (Hart 1990). By contrast, Eyles et al. (1989) interpreted the contorted succession as the product of glaciomarine sedimentation. The presence of large rafts of chalk elevated above the chalk bedrock surface in north Norfolk, a characteristic feature of the 'Contorted Drift', were first recognised by Marshall (1787), Reade (1882), Slater (1927) and later described by Banham $(1975,1988)$ and Hart \& Boulton (1991a).

\section{Methodology}

The three sites were selected because they allowed the detailed study of both largeand small-scale structures associated with the emplacement of the bedrock rafts. In order to understand the overall glaciotectonic structure, measurements were taken using a compass clinometer from all three sites, including the orientation of fold axes, the dip angles of basal shear planes and the bedding within them (Fig. 2). These measurements and observations were used to ascertain the predominant ice flow direction and sequence of events where stacked chalk rafts occur. In addition, foraminifera were analysed from chalk samples obtained to enable the provenance of the chalk rafts relative to the known chalk stratigraphy of the region (Wilkinson 2008). In order to disaggregate the chalk samples and release the microfossils, samples were crushed into 3-5 mm grains, soaked in white spirit for 30 minutes and then boiled in sodium hexametaphosphate for two minutes. The disaggregated samples were then washed through a sieve to remove the $<75 \mu \mathrm{m}$ fraction. Foraminifera were then picked from the residue for identification under a standard microscope. Faunas were compared with those assemblages recognised by Swiecicki (1980) and Hart et al. (1989).

\section{Chalk rafts of the northeast Norfolk coast}

In this section, descriptions and interpretations of chalk rafts and associated glaciotectonic structures are outlined. Sites are described from east to west.

\section{Overstrand}

The Pleistocene glaciogenic sediments exposed in the cliffs at this locality contain three prominent thrust-bound chalk rafts (labelled OV1 to OV3), capped by preglacial sand and gravel (WCF) and till (HTM, BTM). The structurally highest of the rafts (OV3) is poorly exposed and occurs at a much higher elevation within the cliff section, but the accompanying thrust can be seen to truncate HTM and BTM. This part of the section is highly unstable and marked by a number of active landslips. Consequently, no detailed information has been obtained for this raft. 
Foraminifera. - Three samples were collected at the Overstrand site for the examination of foraminifera in order to provide a relative faunal age of the chalk and therefore give information regarding their provenance - sample MPA56765 was collected from an in situ outcrop of chalk on the foreshore, MPA5673 was collected from OV1, MPA56764 from OV2, and MPA56765.

Sample MPA56765, collected from an in situ outcrop within the Overstrand foreshore contains foraminifera that appear to span the Upper CampanianMaastrichtian (Upper Cretaceous) boundary. Ruguloglobigerina rugosa is rare in the highest Belemnitella mucronata Zone, but is essentially a Maastrichtian species. The first appearance of Bolivina incrassata is in the late B. mucronata Zone, and ranges through the lower Maastrichtian. Bolivinoides sidestrandensis also appears in the upper B. mucronata Zone in foraminiferal zone BGS23 (B4i of Swiecicki 1980) and ranges up into the lower Maastrichtian (disappearing within the occidentalis Zone). No species confined to the Maastrichtian were found, suggesting the age of the fauna is mucronata zonal age.

Sample MPA5673 (OV1) contains an Upper Campanian-Maastrichtian (Upper Cretaceous) assemblage of foraminifera. Gavelinella voltziana appears at the base of the B. mucronata zone. Gavelinella eriksdalensis is a long ranging species that is rare in the upper part of its range, but disappears from the record in the upper B. mucronata Zone. Eponides beisseli, on the other hand, first appears in the upper B. mucronata Zone and ranges through into the early Maastrichtian. The concurrent range of these species suggests the upper B. mucronata Zone. No species restricted to the Maastrichtian were found, leading to the conclusion that the raft was of chalk of B. mucronata zonal age. However, it should be pointed out that Gavelinella involuta disappears from the record in the lower part of the B. mucronata Zone and is not normally found in association with Eponides beisseli. The chalk is therefore considered to be of extremely local provenance or derived from further to the north along the strike of the chalk.

Sample MPA56764 from OV2 also contains a range of foraminifera that span the Upper Campanian-Maastrichtian (Upper Cretaceous) boundary. Ruguloglobigerina rugosa is essentially a Maastrichtian species, although it occurs in small numbers in the highest B. mucronata Zone. The first appearance of Bolivina incrassata is in the late B. mucronata Zone. Neoflabellina praereticulata was a short lived species ranging from the uppermost part of the B. mucronata zone to the lower B. lanceolata Zone, and the range of Bolivinoides decoratus is essentially B. mucronata Zone, although rare specimens range up into the basal Maastrichtian (basal B. lanceolata zone). Stilostomella pseudoscripta also appeared in the highest B. mucronata Zone and ranges through the lower Maastrichtian. The best fit is uppermost B. mucronata Zone, although the very basal Maastrichtian cannot be ruled out entirely, no species confined to the Maastrichtian were found. The chalk is once again considered to be of extremely local provenance or having been derived from further to the north along the strike of the chalk. 
Structural description. - The largest of the chalk rafts (OV2, Fig. 3) forms an elongate, slab-like body that dips at a moderate angle (25-35') towards the northwest. Bedding (dip 25-30', strike $245-270^{\circ}$; Fig. 2, data plotted as dip and dip direction) within the raft is well-preserved and defined by laterally extensive layers of nodular flint, which occur parallel to the upper and lower boundaries of the raft. The upper boundary of the chalk is sharp and apparently planar in form, and conformably overlain by bedded sands and gravels (WCF). The WCF is in turn overlain by the HTM and BTM which consist of compact subglacial till. The WCF shows very little evidence of deformation, even immediately adjacent to the underlying chalk. The absence of any obvious glaciotectonic disturbance along this contact has lead to the interpretation that it represents an original (prior to rafting) contact between the chalk and overlying, in-situ, shallow marine deposits (the WCF) (West 1980). A similar, conformable relationship is also preserved at the top of a structurally lower chalk raft (OV1) which is exposed at beach level to the southeast, and dips gently $\left(13^{\circ}\right)$ towards the north (Fig. 2). Bedding and flint horizons within this lower raft dip gently (10$15^{\circ}$ ) towards the north/northwest, suggesting that raft OV1 was emplaced into the glaciogenic sequence at a much shallower angle than the structurally overlying and more steeply dipping raft OV2.

Although the upper boundaries of the rafts at Overstrand preserve the original stratigraphic relationship between the chalk and overlying sediments, the lower bounding surfaces of these rafts are clearly glaciotectonic in origin. The base of OV2 is formed by a prominent northerly dipping thrust zone (Fig. 3) which dips at $35^{\circ}$. This zone $\left(0.5-1.0 \mathrm{~m}\right.$ wide) is composed of a number of moderate (30 to $40^{\circ}$, Fig. 2 ) northerly dipping brittle reverse faults (Figs 2,4). The off-set on these smaller-scale thrusts record an overall sense of movement towards the south. Small, elongate lenses of highly-deformed chalk are locally strung out along these faults. Immediately above the basal thrust, bedding within the chalk raft is poorly preserved and has been variably overprinted by a moderate to steep, mainly northerly dipping fracture cleavage (Fig. 2). A second fracture cleavage is developed at the base of the chalk raft where it occurs parallel to the basal thrust (Fig. 4).

Although typically brittle structures, one of the minor thrusts within the basal part of the chalk raft is marked by a narrow ( $2-3 \mathrm{~cm}$ thick) zone of highly foliated, very finegrained carbonate (possibly mylonitic). No obvious macro-scale kinematic indicators have been recognised within this postulated mylonitic zone.

Deformation within the WCF occurs within a relatively narrow (2-3 m wide) zone immediately beneath the base of the chalk raft. In the basal thrust zone, bedding within the WCF has been modified to form a steep northerly dipping, sigmoidal composite foliation (Fig. 2) that records a southerly directed sense of shear (Fig. 4). This modified bedding is locally off-set by a number of gently dipping shears $(3-4 \mathrm{~cm}$ across) and small-scale thrusts (Figs 3,4). In the immediate footwall to the basal thrust, the sands and gravels of the WCF are deformed by a meso-scale (several metres in amplitude) syncline, with a plunge of $10-20^{\circ}$ towards the west/north-west (Figs. 2, 3, 4). The sub-vertical to slightly overturned upper limb of this fold is 
truncated by the zone of thrusting at the base of the chalk raft. Locally well preserved sedimentary structures (e.g. climbing ripple drift lamination) within the sands show that the lower, moderately northerly dipping limb of the syncline is the right way up (Fig. 4), indicating that emplacement of the chalk rafts at this locality was not accompanied by large-scale overturning of the sedimentary sequence. Deeper within the footwall of the thrust, the sediments are undisturbed and dip at a low to moderate angle towards the north-northwest (Fig. 2), in continuity with chalk raft OV2.

The southern tip of chalk raft OV2 is folded by a large-scale antiform (Fig. 3). This open, southerly verging structure is apparently truncated by the basal thrust. The upper limb of the antiform is further complicated by a steep southerly dipping brittle reverse fault, which occurs below the hinge of an open, weakly asymmetric, northerly-verging fold. This fold locally deforms bedding within the chalk and overlying WCF (Fig. 3) and appears to form above the tip of the underlying fault; the latter being interpreted as a back-thrust.

\section{East Runton}

The glaciogenic sediments exposed within cliff sections at the East Runton site contain five distinct chalk rafts, labelled in order of elevation in the cliff face from ER1 to ER5. As at Overstrand, bedding in the chalk rafts is well preserved and defined by laterally persistent bands of flint nodules. However, in contrast to the sequence exposed at Overstrand, the imbricate stacked sequence of chalk rafts, WCF and glaciogenic sediments exposed at East Runton is structurally more complex (compare Fig. 3 with Figs 5, 6). Due to lack of accessibility, no chalk samples were collected from East Runton for foraminifera analysis.

Structural description. - The lowest of the chalk rafts (ER1) is poorly exposed and its base is largely obscured by debris. Small exposures of a dark grey till beneath raft ER1 suggest that it rests upon HTM (Fig. 5). The upper boundary of raft ER1, however, is better exposed and formed by a northerly dipping (maximum dip 35-45) thrust (T1). The dip of this thrust steepens northwards where it apparently truncates raft ER1 and forms the base of the structurally overlying chalk raft (ER2) (Fig. 5). In this part of the section the T1 thrust occurs parallel to bedding within raft ER2. This raft is approximately 5 to $6 \mathrm{~m}$ thick and at least 35 to $40 \mathrm{~m}$ in length. It tapers southwards, where it is overlain by a very thin sequence of WCF, before being cut out against a branch of the T1 thrust. Bedding in ER2 is relatively steep in the middle of the section, but flattens towards the south (Fig. 5), mimicking the overall sigmoidal/arcuate shape of this chalk raft. The base of the raft is formed by a northerly dipping thrust, which forms a sharp, planar boundary with the underlying Happisburgh Till Member (HTM) (Fig. 7A). Ductile deformation associated with this thrust is concentrated in a narrow (10 to $15 \mathrm{~cm}$ thick) zone within the upper part of the HTM (Fig. 7A). The diamicton within this high strain zone possesses a wispy to crudely planar foliation defined by thin ribbons of disaggregated chalk. This fabric 
wraps around larger, variably rounded clasts of chalk. The upper boundary of ER2 is also tectonic and formed by a second northerly dipping (maximum dip 30-40 ) thrust (T2). This thrust forms the base of the structurally overlying raft ER3 (Fig. 5). The size (3-4 m thick), shape and overall geometry of ER3 is similar to the underlying chalk rafts. However, unlike ER1 and ER2, it is overlain by a 3 to $4 \mathrm{~m}$ thick sequence of WCF. Further to the southeast, the original stratigraphic boundary between the chalk forming raft ER3 and the WCF is exposed lower in the cliff section where the eroded top of the chalk is overlain by a coarse basal gravel lag (Fig. 7B). The chalk within raft ER3 is highly variable and ranges from poorly bedded, to massive, through to highly fragmented or brecciated (Figs 7C, D). Bedding, where preserved, is defined by horizons of nodular flint. The individual flints are locally highly fractured; however, these fractures do not affect the adjacent chalk. Elsewhere, bedding has been variably 'overprinted', with the chalk becoming more massive and putty-like in texture.

Crudely developed/preserved folds within this 'putty-chalk' are defined by chains of nodular flints. In places the chalk is deformed by a set of steep (80-90 $)$ northerly dipping (Fig. 2), closely spaced fractures, which define a relatively well developed fracture cleavage (Fig. 7C). A second, more locally developed, steep easterly dipping fracture cleavage was also noted. The fragmented or brecciated chalk comprises rounded to tabular fragments of chalk in a hematitic to silty matrix (Fig. 7D). Importantly the 'cleaved' chalk and 'chalk-breccia' do not show any obvious spatial relationship to the tectonised margins of the rafts, occurring within the body of the raft. The overall appearance of the 'chalk-breccia' is reminiscent of the highly weathered zone locally present at the top of the in-situ chalk bedrock elsewhere in southeast England (Murton 1996).

Higher in the cliff section, the WCF is in turn overlain by a 2-3 $\mathrm{m}$ thick sequence of brown-grey clay of the HTM (Fig. 5). This till unit can be traced laterally eastwards, where it is cut out against a sub-horizontal to gently southerly dipping thrust (T3). The HTM is more accessible further along the coast, westwards towards West Runton, where it contains highly deformed fragments of chalk and a number of smaller chalk rafts (1-2 $\mathrm{m}$ in length) (Fig. 8A). These included chalk fragments are wrapped by a locally pervasive foliation developed within the till, defined by elongate stringers of very fine-grained chalk. The sense of asymmetry of the chalk rafts (Fig. 8a) and the geometry of small-scale deformation structures (rotated clasts, S-C-like fabrics, asymmetric folds) (Fig. 8B) indicate an overall sense of shear towards the south. Similar tectonised chalk-rich till (referred to as chalk-banded till or chalk-till mélange) has been described associated with the dislocated chalk rafts in Denmark and Germany (Pedersen 2000; Aber \& Ber 2007).

Directly above thrust T5 at East Runton is a thick sequence of well-bedded sands and gravels (Fig. 5) that are deformed by a large-scale (several metres in amplitude), gently inclined syncline. Further east, along the coast, this sand unit is absent and the HTM is directly overlain by a large (10-15 m thick, approximately 80 $\mathrm{m}$ long) chalk raft (ER4 on Fig. 6). As in previously described rafts, bedding within raft ER4 is defined by layers of nodular chalk and occurs parallel to the basal thrust. 
This thrust (T6), although apparently subhorizontal in the exposed section, actually dips at a moderate angle out of the cliff face, towards the north. The raft is overlain by a thick unit of WCF. Bedding within these sands and gravels is relatively undisturbed. The WCF is in turn overlain by yet another slab-like chalk raft (ER5), with the boundary between them being formed by a northerly dipping thrust (T6 on Fig. 6). Further east, the WCF is cut out and the structurally higher raft ER5 rests directly upon ER4, with the thrust plane separating these two stacked slabs of chalk being marked by thin (up to approximately $1 \mathrm{~m}$ thick), tectonised lenses of sand and gravel.

To summarise, the complex sequence of chalk rafts exposed at East Runton represents an imbricate stack, with each slice separated by a northerly dipping thrust. A number of these thrust slices preserve the original stratigraphic relationship between the WCF and underlying chalk bedrock.

\section{West Runton}

The cliff section at West Runton exposes a highly deformed sequence of glaciogenic sands, the Runton Sand and Gravel Member (RSGM), overlying the BTM and basal HTM. This highly deformed sequence contains rafts of both WCF and chalk bedrock (Figs 8C, D). In-situ chalk bedrock is locally exposed on the beach between the mean high tide and low tide marks. The range of deformation structures present within the sediments at West Runton has been described in detail by Hart \& Boulton (1991b), Hart \& Roberts (1994), Roberts \& Hart (2005) and Phillips et al. (2008) and are only summarised here. Two chalk samples were collected for foraminifera analysis MPA56766, from in situ chalk bedrock on the foreshore, and MPA56767 from a chalk raft exposed in till.

Foraminifera. - Foraminifera from MPA56766 demonstrate that chalk bedrock at West Runton lies within the Belemnitella mucronata Zone. The extinction point of Gavelinella clementiana laevigata is within the upper part of the B. mucronata Zone, in foraminiferal zone BGS23 (low in B4i of Swiecicki 1980). The inception of Reussella szajnochae, on the other hand, is at the base of foraminiferal zone BGS22 (equating to B3iv of Swiecicki 1980) ('mid' B. mucronata Zone). Heterohelix complanata first appears near the base of foraminiferal zone BGS23. The concurrent range of these species places the fauna in the 'foraminiferal zone BGS23, and 'mid' to late (but not latest) B. mucronata Zone. Gavelinella monterelensis is confined to the mucronata Zone.

Foraminifera within the chalk raft (MPA56767) place the chalk within the B. mucronata Zone (Upper Campanian). The chalk raft is, therefore, either derived locally or has been transported along the north-south strike of the chalk. Globorotalites michelinianus is a long ranging species that disappears from the record in the 'mid' B. mucronata zone. It is consistently present in the lower part of the B. mucronata Zone, but becomes rare and patchily distributed in the upper part of its range. It occurrence here suggests the assemblage is no higher than foraminiferal zone BGS21; the species has not been recorded in BGS22, although rare specimens have been recorded in the 
basal part of foraminiferal zone BGS23. Neoflabellina rugosa goes into extinction at the top of foraminiferal zone BGS23.

Structural description. - The succession at West Runton is thought to record the progressive proglacial to subglacial deformation of older glaciogenic sediments (HTM and BTM) overlain by a penecontemporaneous sequence of well bedded glacial outwash sands and gravels (Phillips et al. 2008). At the eastern end of the cliff section the relatively intact sands and gravels of the RSGM are locally deformed by a number of gently to steeply inclined thrust faults. Thrusting has resulted in the introduction of tectonically bounded 'wedges' or 'slices' of BTM and local lacustrine marls into the sands. Further west, ice-marginal thrusting and folding apparently resulted in the repetition and stacking of the RSGM with thrust-bound slices of WCF, HTM, marl and BTM. Further to the west, the HTM, BTM and RSGM have undergone more pervasive subglacial deformation, resulting in ductile shearing and disruption of the sands, as well as thrusting and folding of the tills (Phillips et al. 2008).

At the western end of the West Runton section, within the highly deformed subglacial part of the succession, the HTM contains several thin (10-50 cm thick), but relatively laterally extensive (up to $15-20 \mathrm{~m}$ in length), rafts of chalk overlain by WCF (Figs 8C, D). However, unlike at Overstrand and East Runton, the chalk rafts at West Runton are relatively flat-lying and show no signs of imbricate stacking seen at the other localities. Bedding within the rafts at West Runton is very poorly preserved, with the individual rafts being composed of massive, locally very soft 'putty-like' chalk, containing isolated flint nodules. The HTM immediately below these chalks rafts contains highly deformed stringers and rounded to elliptical clasts of chalk, which are wrapped by a locally well developed glaciotectonic foliation present within the till (Figs 8C, E). The individual chalk clasts are variably enclosed within symmetrical to asymmetric pressure shadows or elongate tails, composed of finegrained carbonate, forming asymmetric porphyroclast systems (Passchier \& Trouw 1996). The asymmetry of these rotated chalk clasts records an overall sense of shear towards the east. Unlike at the other sites, the HTM at West Runton was 'reworked' during a later glacitectonic event, which post-dated raft emplacement and as was associated with ice advancing from the west (Phillips et al. 2008). This later event led to the modification of earlier deformation structures present within the HTM, leading to the easterly directed shear sense recorded by the small scale kinematic indicators. The boundary between the chalk and the HTM is typically sharp and apparently planar in form. Locally, however, elongate flame-like ribbons of chalk can be seen extending from this contact (Fig. 8C). These ribbons appear to have been 'pulled' from the raft during deformation.

The overall appearance and range of structures present within the chalk-rich till (Fig. 8e) are similar to those present within mylonitic rocks (see Passchier \& Trouw 1996), suggesting that the chalk and HTM have undergone locally intense ductile shear. Internally, however, the chalk rafts show very little or no evidence of 
this ductile shear event. Furthermore, the chalk is locally immediately overlain by the basal shelly gravel lag of the WCF (Fig. 8D). This sharp, planar to slightly irregular, boundary is interpreted as representing the original stratigraphic boundary between the two units. This contact would have represented a major plane of weakness within the deforming sedimentary pile. However, well preserved shells, including almost complete valves, occur within the basal lag of the WCF.

\section{Discussion: glaciotectonic model for chalk rafting in North Norfolk}

Tills on the north Norfolk coast were emplaced by British ice during the Middle Pleistocene, although debate surrounds whether they were laid down during a single glaciation as conventional models suggest (Perrin et al. 1979; Bowen et al. 1986; Ehlers \& Gibbard 1991; Bowen 1999), or during several different glacial episodes (Hamblin et al. 2000, 2005; Clark et al. 2004). The predominant ice movement direction, indicated by the orientation of bedding, sense of displacement on the thrusts at the base of the chalk rafts and kinematics provided by associated deformation structures within the sediment pile, was from the north to northwest. This is consistent with ice flowing into the region from the North Sea offshore region between Lincolnshire and Norfolk.

\section{$\underline{\text { Source of the chalk rafts }}$}

Palaeontological evidence presented here demonstrates that the chalk rafts at Overstrand and West Runton were derived from the Belemnitella mucronata Zone (Upper Campanian) and Belemnitella lanceolata Zone (Maastrichtian) of the White Chalk Subgroup. The same faunal biozones occur with chalk bedrock exposed along the foreshore at both Overstrand and West Runton, indicating that the chalk rafts are either locally derived (i.e. immediately offshore), or have been transported southwards along the strike of the chalk.

Although an offshore location can be demonstrated for the source of the chalk rafts based on palaeontological and structural evidence, the exact location of this source and the distance travelled by the detached bedrock slabs remains unknown. Consequently, the conditions required to trigger the glacial rafting of the chalk bedrock must also remain speculative. The position of the rafts within or beneath thick till sequences (the HTM and BTM) suggests that detachment did not occur in response to the freezing of these chalk bedrock slabs to the base of the overriding ice. A glacitectonic/thrust model (c.f. Ruszczynska-Szenajch 1987) is therefore favoured for the initial detachment of the chalk rafts exposed along the northeast Norfolk coast.

It is probable that thrusting and raft detachment initially occurred as the ice encountered a regional-sized 'obstacle' within its path. The provenance and distribution of the chalk rafts, encompassing zones of chalk that lie perpendicular to the north-south strike of the chalk, suggest that this obstacle was not constrained by the regional dip of the chalk surface and that the obstacle was aligned broadly parallel to the trend of the modern coastline. Possible obstacles could include a 
palaeo-coastline or pre-existing morainic landform, or perhaps a change in subglacial geology from soft-sediment to chalk-dominated substrate. The build-up of strain and pore water pressure on the up-ice side of such features would have focused stresses along major lateral discontinuities within the chalk such as joints and bedding planes, with brittle failure and thrusting leading to the detachment of slab-like blocks of bedrock (Fig. 9). The repeated detachment of the thrust-bound chalk rafts would eventually degrade the topographic feature leading to the cessation of rafting. At present, there is insufficient evidence to determine the exact source locality of the chalk rafts. However, one such possible source is the offshore area located immediately to the north of the study sites. Examination of the seabed topography reveals a distinctly undulating upper surface to the chalk (British Geological Survey 2002). One possible interpretation for these undulations is that they are glaciotectonic hill-hole pairs (Banham 1975; Benn \& Evans 1998) that have been partially degraded by marine processes.

Preservation of the stratigraphical relationship between the chalk and Wroxham Crag Formation during rafting

Although glaciotectonic thrusting can be invoked to account for the initial detachment of the chalk rafts, it does not explain the preservation of the primary stratigraphic relationship between the chalk and the overlying WCF. This boundary is preserved in a significant number of the rafts exposed at Overstrand, East Runton and West Runton. The inherent competence contrast between the chalk bedrock and unconsolidated WCF would have meant that this erosional contact would have formed a major plane of weakness within the sequence, thus as the sequence began to deform, the developing thrusts/detachments would have preferentially formed along this boundary. However, no evidence of deformation has been found along this boundary. In fact, complete undeformed shells are preserved within the basal lag of the WCF immediately above the chalk in rafts at all three study sites. Thrusting, leading to detachment of the rafts, appears to have occurred within the chalk (thickest raft 20-25 m thick), with the décollement surfaces occurring parallel to bedding. At East Runton and Overstrand, deformation associated with detachment of the rafts is typically focused along the thrust zones at the base of the bedrock slabs. Deformation in the hanging walls of these structures is relatively limited. Folding of the chalk and WCF observed in the Overstrand and East Runton sections is thought to have occurred during the stacking and emplacement of the rafts, rather than their initial detachment (see below).

One model which could explain the preservation of the chalk bedrock-WCF boundary intact is one involving either polythermal or cold-based ice. In this model the original stratigraphic relationship between the two units would have remained intact due to the WCF and chalk being frozen (permafrost) during initial detachment, transport and subsequent accretion/deposition of these ice-rafted slabs. The WCF sediments may have become frozen to the chalk bedrock due to the development of a permafrost layer of variable thickness (1-25 m based on the range of thickness of the 
rafts) either in front of or beneath the advancing North Sea ice. It is possible that the base of the chalk rafts correspond to the bottom of this postulated permafrost layer, thus enabling the WCF and chalk bedrock to be detached as a single block, with the chalk-WCF rafts representing detached fragments of the permafrost layer. The existence of permafrost in northern East Anglia prior to and during Middle Pleistocene glaciation is well established (Rose \& Allen 1977; West 1980; Fish et al. 1998; Briant et al. 1999; Whiteman 2002). Soft-sediment glaciotectonic structures such as disharmonic folds and large-scale water-escape conduits, indicate that the sediment pile was not completely frozen during deformation (Roberts \& Hart 1994) and that the pore water content and/or pressure fluctuated during deformation (Phillips et al. 2008). A possible explanation for this is that this deforming sediment pile was part of a relatively thick mobile 'active layer' that existed above the permanent permafrost in front of and/or beneath the advancing ice sheet.

Previous research has suggested that structures in chalk, such as bedding, are variably susceptible to break-down under the influence of repeated freeze-thaw and salt crystallisation, especially when the chalk is saturated with salt water (Jerwood et al. 1990). Disaggregation of the chalk leads to the development of a 'putty-like' consistency (Younger 1989) - a process that may have resulted in the homogenisation of the chalk within the raft at the western end of the West Runton section. This process may also explain the locally massive, putty-like appearance of the chalk in some of the large, slab-like rafts at East Runton and the smaller blocks present within the HTM at West Runton. However, the large-scale preservation of bedding within the chalk rafts implies that pore water content within the chalk was, in general, relatively low upon freezing.

\section{Role of pressurised pore water during the detachment of the chalk rafts}

Although the upper layer of the chalk and WCF may have been frozen, detachment at depth within the chalk may have been controlled by another mechanism. Previous work on ice-rafted bedrock and soft-sediment slabs have suggested that failure, leading to detachment, can be associated with elevated pore water pressures, or as a result of the freezing of the bedrock to the base of the ice. Such water-rich décollement surfaces may occur within the subglacially deforming layer (Moran et al. 1980; Aber 1985; Broster \& Seaman 1991; Benn \& Evans 1998; Phillips \& Merritt 2008), at the base of this deforming layer (Kjær et al. 2006), or at a deeper level within the bed as a consequence of subglacial hydrofracturing by forceful upward dewatering (Boulton \& Caban 1995; Rijsdijk et al. 1999). The role played by pressurised pore water (i.e. hydrofracturing) during both subglacial and, to a lesser extent, proglacial deformation, is increasingly being recognised within tectonised glaciogenic sequences (Boulton \& Caban 1995; Hiemstra \& van der Meer 1997; Rijsdijk et al. 1999; van der Meer et al. 1999; Phillips \& Auton 2000; Boulton et al. 2001; Khatwa \& Tulaczyk 2001; Phillips 2006, Baroni \& Fasano 2006; Phillips et al. 2007; Lee \& Phillips 2008; Phillips et al. 2008). Although soft sediment deformation, hydrofracturing and liquefaction can occur in both subglacially and proglacially deformed sequences 
(Rijsdijk et al. 1999; Baroni \& Fasano 2006), structures equated with high pore water pressures and contents may be more widely/pervasively developed in subglacially deformed sediments (Phillips et al. 2007). Phillips \& Merritt (2008) have argued that the transport of glacial rafts may, in some cases, be assisted by the presence of waterlubricated detachments within the deforming sediment pile.

Hart \& Boulton (1991a) have suggested that the base of the North Sea ice sheet was frozen to the surface of the underlying chalk bedrock, with detachment of rafts occurring as the ice rode over the bedrock surface, stripping/plucking off elongate slabs of chalk. Once a raft became detached, many of the published models suggest that it was transported by incorporation into the base of a glacier (Clayton \& Moran 1974; Bluemle \& Clayton 1984). This would require a compressive flow regime within the glacier, leading to an upward component of motion, allowing the rafts to be sheared into the base of the ice as a result of the decreased effective stress caused by elevated pore water pressure (Bluemle \& Clayton 1984). Freezing of such large volumes of chalk (40-80 m long by $15-20 \mathrm{~m}$ thick) to the glacier bed would require the base of the ice sheet to be cold-based. If freezing of the ice sheet to its subglacial bed occurred, it is probable that shearing may have been accommodated by thrusting within the structurally higher basal ice layers, rather than the bedrock. However, the presence of a thick sediment pile between the rafts and the upper limit of thrusting at Overstrand would indicate that this cold-based model is not supported by field evidence. Furthermore, at East and West Runton, chalk rafts occur within tills that contain abundant evidence for elevated pore water pressures/contents at the time of deformation (Hart \& Roberts, 1994; Roberts \& Hart 2005; Phillips et al. 2008). This suggests that these large chalk rafts were more likely to have been transported within a deforming sediment pile beneath the glacier in an ice-marginal to subglacial setting.

The preservation of the original stratigraphic relationships between the chalk and overlying WCF within many of the rafts has been used to suggest that these thrust-bound blocks were frozen during rafting (see above). Coupled with the evidence for a deforming water-rich sediment pile adjacent to the chalk rafts, this indicates that rafting occurred beneath polythermal ice. The presence of a relatively impermeable permafrost horizon beneath the glacier would have acted as an impermeable barrier within the deforming bed, potentially focusing subglacial water flow into the overlying sediment pile or active layer. Pre-existing planes of weakness, such as joints, faults and bedding surfaces may have allowed pressurised pore water to penetrate into the underlying bedrock beneath the permafrost layer. The introduction of pressurised melt water along the pre-existing structures, coupled with repeated cycles of freeze thaw in the postulated polythermal subglacial environment, would have resulted in the further weakening of the bedrock mass. As a result, thrusting would have preferentially occurred along these laterally-extensive planes of weakness, aiding detachment of the chalk rafts.

At Overstrand and East Runton the planes of weakness exploited by the basal thrusts of the rafts appear to relate to bedding within the chalk. Narrow, apparently 
mylonitic zones of fine-grained chalk observed marking one of the thrusts at the base of raft OV2 at Overstrand may be preserving the intense deformation associated with detachment. The majority of exposed thrusts, however, are brittle and have very little or no evidence of any associated ductile deformation within the adjacent chalk. Therefore, these postulated mylonitic zones may record processes occurring during the initial detachment phase of the rafting process.

Imbricate thrust stack model for the emplacement of the chalk rafts

The geometry of the chalk rafts exposed at Overstrand clearly replicates a simple imbricate thrust stack model (Fig. 10A). The first bedrock slab to be emplaced was the relatively shallowly dipping raft OV1, after which OV2 was thrust over the top. Deformation of the WCF occurred as OV2 overrode OV1, folding the WCF into a footwall syncline. As the raft OV2 was emplaced onto the developing thrust stack it folded, forming a broad open hanging wall anticline, which also affected the overlying WCF (Figs 3, 10A). OV3 was then thrust above OV2. It is likely that these rafts were still frozen during emplacement and overriding of subsequent rafts. This is evident in the preservation of the chalk/WCF contact and the brittle deformation (back-thrust) observed in OV2. Furthermore, bedding within the WCF remains relatively undisturbed during the over-thrusting of later chalk rafts.

The section at East Runton is more complex (Figs 5, 6), but the geometry of the chalk rafts can be interpreted in terms of a duplex, produced by multiple phases of thrusting. The overall superposition of the rafts ER1-ER3 indicates that they were sequentially emplaced (ER1 earliest, ER3 latest) during an earlier phase of thrusting, with structurally higher rafts ER4 and ER5 being transported over this early formed thrust stack during a second, later phase of thrusting (Fig. 10B). Deposition of the HTM is likely to have occurred during thrusting, possibly commencing during the emplacement of rafts ER1-ER3. The till was subsequently deformed during the second phase of thrusting, which resulted in the emplacement of raft ER4, with the HTM becoming incorporated into the developing thrust duplex (Fig. 10B). The HTM is strongly foliated at this locality (Figs 8A, B), concordant with the structural orientation of thrust T4, associated with the emplacement of ER4.

Further up-ice, at West Runton, the HTM contains highly deformed and fragmented chalk rafts (Fig. 8C, D, E). The complex deformation structures observed at West Runton completely obscure the original relationship between the chalk rafts and their host sediments. This raft is much thinner and more laterally extensive than those at Overstrand and East Runton. At this locality the chalk raft has been fully incorporated into the HTM and both show signs of shearing. Large and small-scale deformation features within the HTM, such as foliation and asymmetric 'sheared' chalk clasts (Fig. 8E), are directly associated with overriding ice. Although the original bedding and basal detachment/shear surface of the raft are not clearly visible in this section, the WCF/chalk contact is well preserved. 


\section{Timing of glaciotectonic rafting}

The cross-cutting relationship between thrusts, chalk rafts and the various till units in north Norfolk enable the relative timing of chalk rafting to be determined. Sections at Overstrand reveal that thrusts associated with raft emplacement truncate both the HTM and BTM, indicating that rafts were emplaced during the accretion of the latter or perhaps during a subsequent ice-marginal oscillation. Undeformed (internally) WCF remains attached to the top surface of the chalk rafts at all three study sites, suggesting that the WCF remained frozen from initial detachment to final emplacement, implying that the entire rafting process probably occurred over a relatively short time period - i.e. a single glaciation rather than multiple glaciations.

\section{Glaciotectonic model for raft emplacement along the north Norfolk coast}

It is clear from preceding descriptions of the ice-rafted sequences at Overstrand, East Runton and West Runton that there is a systematic variation in the complexity and intensity of deformation from south-east to north-west along the north Norfolk coast. This variation, coupled with the overall southerly directed sense of displacement recorded by the bounding thrusts and associated folds, are consistent with rafting having occurred in response to ice advancing from the north to northwest.

Consequently, the emplacement of the chalk rafts exposed at Overstrand, East Runton and West Runton are thought to have occurred during the same glacitectonic event which accompanied the deposition of the BTM. The sequence at Overstrand represents the most southerly of the exposed rafts studied, with thrusting leading to the simple stacking of chalk rafts with the pre-glacial sands and gravels of the WCF (Fig. 10A). In contrast, at East Runton the sequence is far more complex with the rafts occurring tectonically interleaved with both pre-glacial (WCF) as well as glacial sediments (HTM/BTM), forming a duplex (Fig. 10B). At West Runton, deformation is most intense with the chalk rafts undergoing dismemberment, to be incorporated into the subglacial HTM. These marked contrasts in the structural style can be directly related to relative position of the three sites within the developing thrust complex during glaciotectonism (see Fig. 11A). This thrust complex propagated southwards as ice advancing from the north began to impinge on the north Norfolk coast (Figs 11B to D).

The rafts at Overstrand exhibit relatively little evidence of deformation internally, suggesting that they have only undergone a limited period of transport and are, therefore, probably in close proximity to their original source area. This hypothesis is substantiated by the foraminiferal assemblage within the chalk (raft OV2), which places the rafts in close proximity to their area of derivation, slightly offshore. As previously stated, the chalk rafts at Overstrand are tectonically thrust over pre-glacial (WCF) sediments with associated thrusts cutting through overlying glacial sediments (HTM/BTM) (Fig. 10A), implying that the transport and subsequent accretion of the chalk rafts are most likely to have occurred in a proglacial to icemarginal setting (Fig. 11) (cf. Banham 1975; Christiansen \& Whitaker 1976; Moran et al. 1980; Bluemle \& Clayton 1984; Ruszczynska-Szenajch 1987). In contrast, at East 
Runton, rafts are totally enclosed by till, potentially ruling out proglacial deformation as the sole mechanism leading to the accretion of these bedrock slabs (cf. Banham 1975; Aber 1988). In this case, raft emplacement/accretion is thought to have been initiated beneath the ice sheet, in either an ice-marginal or subglacial setting (Figs 11C, D). However, as at Overstrand, initial detachment of the rafts at East Runton may have occurred in response to proglacial thrusting; but probably further off-shore, allowing a greater period of time and lateral distance for these detached chalk rafts to be overridden and incorporated into the deforming bed of the glacier. Transportation beneath the advancing ice sheet may have been assisted by the introduction of pressurised water along the thrusts; the latter providing ideal fluid pathways for the escape/migration of subglacial meltwater (cf. Phillips \& Merritt 2008).

In contrast to the other two sites, the West Runton rafts are highly deformed and show evidence of being incorporated into the deforming bed of the ice sheet. This difference could reflect a longer transportation history, or the possibility that the chalk that forms the raft has been periglacially altered and is therefore of lower competence than rafts at adjacent sites. However, subsequent deformation has variably modified and overprinted the original relationships of these rafts with the host sediments, so any interpretation must remain speculative.

Although the emplacement of the chalk rafts at Overstrand and East Runton can be interpreted in terms of a relatively simple thrust model (Fig. 11A), the cause of this accretion event is uncertain. Imbrication and stacking of the chalk rafts may have been initiated due to the 'cessation' or 'stalling' in the forward propagation of the icemarginal/subglacial thrust system. This could have occurred in response to the presence of an obstruction (e.g. a topographic feature) in the path of the advancing ice sheet (Figs 11C, D), or marked change in the properties within the deforming bed (e.g. a collapse of the subglacial hydrodynamic system) at its margin. The latter may reflect differences in the subsurface geology, such as a change from a relatively chalk-dominated substrate to one dominated by pre-existing superficial cover (e.g. WCF, HTM, BTM etc).

At East Runton raft emplacement can be divided into two stages: (i) an early phase of stacking leading to accretion of rafts ER1 to ER3 (Figs 10B and 11C); followed by (ii) a later phase of out of sequence thrusting, leading to the emplacement of rafts ER4 and ER5 (Figs 10B, 11D) and the overriding of this duplex and the deposition a thick layer of HTM above these stacked chalk bedrock slabs (Fig. 10B). The out of sequence thrusting indicates that there was a 'backwards jump' from the more normal thrust propagation at the front of the propagating thrust complex at or near to the leading edge of the advancing ice sheet (i.e. proglacial thrusting), leading to renewed subglacial thrusting in an up-ice position (Fig. 11D). This 'backwards jump' in thrust propagation may have been caused by a cessation of forward movement at the leading edge of the glacier, with the pressure generated by the build-up of ice pushing against the stalled leading edge being accommodated by up-ice out of sequence thrusting. Restricted forward motion of the ice margin may 
have resulted in the relatively simple proglacial/ice marginal thrusting and raft emplacement seen at Overstrand. If correct, this would suggest that as the ice sheet advanced southwards from the lowland area now occupied by the western North Sea onto the relatively higher ground of north Norfolk. Forward motion was achieved as a series of pulsed advances, with each still stand in ice sheet advance being accompanied by raft accretion (Fig. 11D). This model is supported by the overall decreasing complexity of deformation from East Runton in the north, to Overstrand to the south (see Fig. 11A).

\section{Conclusions}

- Foraminifera assemblages and structural measurements taken from glaciotectonic rafts at Overstrand, East Runton and West Runton demonstrate that the rafts are derived locally from chalk bedrock sources located to the north of the study area within the present offshore zone.

- Initial detachment occurred along pre-existing planes of weakness within the chalk bedrock (joints, bedding planes, base of permafrost), relating to the build-up of shear stresses and pore water pressure up-ice of an east-west trending obstruction, represented by either a marked change in glacier bed lithology or topographic feature such as a palaeo-shoreline or morainic feature.

- The preservation of the WCF/chalk contact indicates that the rafts were frozen to the overlying Quaternary sediments as detachment and emplacement occurred, indicating a relatively short period of time between the two. The position of the rafts either above or within the basal deforming bed (represented by the HTM/BTM) demonstrates that the rafts were not frozen to the base of the glacier, but transported within the subglacial deforming bed/active layer.

- Pressurised pore water may have played an important role within the glaciotectonic model, aiding detachment and thrust propagation.

- The northerly dip of the basal thrust planes, bedding and jointing within the rafts, coupled with the overall increasing intensity of deformation from Overstrand in the south to West Runton in the north are indicative of an overall north to south directed ice advance.

- An imbricate thrust stack model is used to explain the glaciotectonic rafting along the north Norfolk coast. At Overstrand, the rafts are stacked in a simple imbricate thrust stack. At East Runton, raft emplacement led to the development of a duplex (ER1-ER3) with out of sequence thrusting (ER4 and ER5) occurring at a later stage in the development of this structure. By contrast, at West Runton, the rafts have been fragmented and incorporated into the HTM, suggesting that perhaps they are furthest travelled.

- The style of deformation at Overstrand suggests that the rafts were transported and accreted in a proglacial position, whilst those at East and 
West Runton were transported and accreted in a ice-marginal to subglacial setting.

\section{Acknowledgements}

The authors wish to acknowledge Nick Golledge, Peter Balson, Jane Hart, Julian Murton, Richard Waller and Colin Whiteman for their earlier thoughts and discussions. We would also like to thank James Aber, Stephen Hicock and Jan Piotrowski for their constructive and helpful comments regarding the manuscript. The authors publish with the permission of the Executive Direction of the British Geological Survey (NERC). 


\section{References}

Aber, J. S. 1985: The character of glaciotectonism. Geologie en Mijnbouw 64, 389-395.

Aber, J.S. 1988: Ice-shoved hills of Saskatchewan compared with Mississippi Delta mudlumps: implications for glaciotectonic models. In Croot, D.G. (ed.): Glaciotectonic Forms and Processes, 1-9. Balkema, Rotterdam.

Aber, J. S. 1989: Spectrum of constructional glaciotectonic landforms. In Goldthwait, R. P. \& Matsch, C. L. (eds.): Genetic Classification of Glacigenic Deposits, 281-292.

Balkema, Rotterdam.

Aber, J. S. \& Ber, A. 2007: Glaciotectonism, 246pp. Developments in Quaternary Science 6. Elsevier, Amsterdam.

Banham, P.H. 1968: A preliminary note on the Pleistocene stratigraphy of north-east Norfolk. Proceedings of the Geologists' Association 79, 469-474.

Banham, P. H. 1975: Glaciotectonic structures: a general discussion with particular reference to the contorted drift of Norfolk. In Wright \& A. E., Moseley, F. (eds.): Ice Ages: Ancient and Modern, 69-94. Seel House Press, Liverpool.

Banham, P. H. 1977: Glaciotectonites in till stratigraphy. Boreas 6, 101-105.

Banham, P. H. 1988: Polyphase glaciotectonic deformation in the Contorted Drift of Norfolk. In Croot, D.G. (ed.): Glaciotectonics: Forms and Processes, 27-32. Balkema, Rotterdam.

Baroni, C. \& Fasano, F. 2006: Micromorphological evidence of warm-based glacier deposition from the Ricker Hills Tillite (Victoria Land, Antarctica). Quaternary Science Reviews 25, 976-922.

Benn, D. I. \& Evans, D. J. A. 1998: Glaciers and Glaciation. 734pp. Arnold, London.

Bluemle, J. P. \& Clayton, L., 1984: Large-scale glacial thrusting and related processes in North Dakota. Boreas 13, 279-299.

Boulton, G. S. 1975: Processes and patterns of subglacial sedimentation: a theoretical approach. In Wright, A. E. \& Moseley, F. (eds.): Ice Ages: Ancient and Modern, 7-41. Seel House Press, Liverpool.

Boulton, G. S. \& Jones, A. S. 1979: Stability of temperate ice caps and ice sheets resting on beds of deformable sediment. Journal of Glaciology 24, 29-43. 
Boulton, G. S. \& Caban, P. 1995: Groundwater flow beneath ice sheets, Part II. It's impact on glacier tectonic structures and moraine formation. Quaternary Science Reviews 14, 563-587.

Bowen, D. Q. (ed.). 1999: A revised correlation of Quaternary deposits in the British Isles. 174pp. Geological Society of London Special Report No. 23.

Bowen, D. Q., Rose, J., McCabe, A. M. \& Sutherland, D. G., 1986: Quaternary Glaciations in England, Ireland, Scotland, and Wales. Quaternary Science Reviews 5, 299-340.

Briant, R. M., Rose, J., Branch, N. P. \& Lee, J. A., 1999. ‘Pre-glacial' Quaternary sediments from Trimingham, north Norfolk, England. Bulletin of the Geological Society of Norfolk 49, 15-47.

British Geological Survey. 2002: Cromer. England and Wales Sheet 131. Solid and Drift Geology. 1:50,000. Keyworth, Nottingham: British Geological Survey.

Broster, B. E. \& Seaman, A. A. 1991: Glacigenic rafting of weathered granite: Charlie Lake, New Brunswick. Canadian Journal of Earth Sciences 28, 649-654.

Christiansen, E. A. \& Whitaker, S. H. 1976: Glacial thrusting of drift and bedrock. Glacial till, an interdisciplinary study, 121-130. Royal Society of Canada Special Publication no. 12.

Clark, C. D., Gibbard, P. L. \& Rose, J. 2004: Pleistocene glacial limits in England, Scotland and Wales. In Ehlers, J. \& Gibbard, P.L. (eds.): Quaternary Glaciations - Extent and Chronology, Part I: Europe, 47-82. Elsevier, Amsterdam.

Clarke, P. U. 1987: Subglacial sediment dispersal and till composition. Journal of Geology 95, 265-287.

Clayton, L. \& Moran, S. R., 1974: A glacial process-form model. In Coates, D. R. (ed.): Tills and Glaciotectonics, 183-195. Balkema, Rotterdam.

Ehlers, J. \& Gibbard, P. L. 1991: Anglian glacial deposits in Britain and the adjoining offshore regions. In Ehlers, J., Gibbard, P. L. \& Rose, J. (eds.): Glacial Deposits of Great Britain and Ireland, 17-24. Balkema, Rotterdam.

Eyles, N., Eyles, C. H. \& McCabe, A. M. 1989: Sedimentation in an ice-contact subaqueous setting: the mid-Pleistocene 'North Sea Drift' of Norfolk, UK. Quaternary Science Reviews 8, 57-74. 
Fish, P. R., Carr, S. J., Rose, J., Hamblin, R. J. O. \& Eissmann, L. 1998. A periglacial composite-wedge cast from the Trimingham area, North Norfolk, England. Bulletin of the Geological Society of Norfolk 46, 11-16.w

Hamblin, R. J. O., Moorlock, B.S.P. \& Rose, J. 2000: A New Glacial Stratigraphy for Eastern England. Quaternary Newsletter 92, 35-43.

Hamblin, R. J. O., Moorlock, B. S. P., Rose, J., Lee, J. R., Riding, J. B., Booth, S. J. \& Pawley, S. M. 2005: Revised Pre-Devensian glacial stratigraphy in Norfolk, England, based on mapping and till provenance. Geologie en Mijnbouw 84, 77-85.

Hart, J.K. 1990: Proglacial glaciotectonic deformation and the origin of the Cromer Ridge push moraine complex, North Norfolk, England. Boreas 19, 165-180.

Hart, J. K. 2007: An investigation of subglacial shear processes from Weybourne, Norfolk, UK. Quaternary Science Reviews 26, 2354-2374.

Hart, J.K. \& Boulton, G.S. 1991a. The glacial drifts of Norfolk. In Ehlers, J., Gibbard, P. L. \& Rose, J. (eds.): Glacial Deposits of Great Britain and Ireland, 233-243. Balkema, Rotterdam.

Hart, J. K. \& Boulton, G. S., 1991b: The interrelationship between glaciotectonic deformation and glaciodeposition. Quaternary Science Reviews 10, 225-250.

Hart, J. K. \& Roberts, D. H. 1994: Criteria to distinguish between glaciotectonic and glaciomarine sedimentation: 1-deformational styles and sedimentology. Sedimentary Geology 91, 191-213.

Hart, M. B., Bailey, H. W., Crittenden, S., Fletcher, B. N., Rice, R. J. \& Swiecicki, A. 1989. Cretaceous. In Jenkins, D. G. \& Murray, J. W. (eds.): Stratigraphical Atlas of Fossil Foraminifera - Second Edition, 273-371. Ellis Horwood, Chichester.

Hiemstra, J. F. \& van der Meer, J. J. M. 1997: Pore-water controlled grain fracturing as indicator for subglacial shearing in tills. Journal of Glaciology 43, 446-454.

Jerwood, L. C., Robinson, D. A. \& Williams, R. B. G. 1990: Experimental frost and salt weathering of chalk - II. Earth Surface Processes and Landforms 15, 699-708.

Khatwa, A. \& Tulaczyk, S. 2001: Microstructural interpretations of modern and Pleistocene subglacially deformed sediments: the relative role of parent material and subglacial processes. Journal of Quaternary Science 19, 507-517.

Kjær, K. H, Larson, E., van der Meer, J. J. M., Ingólfsson, Ò, Krüger, J., Benediktsson, İ. Ö., Knudsen, C. G. \& Schomacker, A. 2006: Subglacial decoupling at the 
sediment/bedrock interface: a new mechanism for rapid flowing ice. Quaternary Science Reviews 25, 2704-2712.

Lee, J. R. \& Phillips, E. 2008: Progressive soft sediment deformatio within a subglacial shear zone - a hybrid mosaic-pervasive deformation model for Middle Pleistocene glaciotectonised sediments from Eastern England. Quaternary Science Reviews 27, 1350-1362.

Lee, J. R., Booth, S. J., Hamblin, R. J. O., Jarrow, A. M., Kessler, H., Moorlock, B. S. P., Morigi, A. N., Palmer, A., Pawley, S. J., Riding, J. B. \& Rose, J. 2004: A new stratigraphy for the glacial deposits around Lowestoft, Great Yarmouth, North Walsham and Cromer, East Anglia, UK. Bulletin of the Geological Society of Norfolk 53, 3-60.

Lee, J. R., Rose, J., Riding, J. B., Hamblin, R. J. O., Moorlock, B. S. P., 2002. Testing the case for a Middle Pleistocene Scandinavian glaciation in Eastern England: evidence for a Scottish ice source for tills within the Corton Formation of East Anglia, UK. Boreas, 31: pp 345-355.

Lunkka, J.P. 1994: Sedimentation and lithostratigraphy of the North Sea Drift and Lowestoft Till Formations in the coastal cliffs of northeast Norfolk, England. Journal of Quaternary Science 9, 209-233.

Marshall, W., 1787: The Rural Economy of Norfolk. London.

Moorlock, B. S. P., Hamblin, R. J. O., Booth, S. J. \& Woods, M. A., 2002: Geology of the Cromer district - a brief explanation of the geological map Sheet 131 Cromer, 37pp. British Geological Survey, HMSO, London.

Moran, S. R. 1971: Glacitectonic structures in drift. In Goldthwaite, R. P. (ed.): Till: A Symposium, 127-148. Ohio State University Press, Ohio.

Moran, S. R., Clayton, L., Hooke, R. L., Fenton, M. M. \& Andriashek, L. D. 1980: Glacier-bed landforms of the prairie region of North America. Journal of Glaciology 25, 457-476.

Mortimore, R.N., Wood, C. J. \& Gallois, R. W. 2001. British Upper Cretaceous Stratigraphy, Peterborough, Joint Nature Conservation Committee.

Murton. J. B. 1996: Near-surface brecciation of Chalk, Isle of Thanet, southeast England: a comparison with ice-rich brecciated bedrocks in Canada and Spitsbergen. Permafrost and Periglacial Processes 7, 153-164. 
Passchier, C. W. \& Trouw, R. A. J. 1996: Micro-tectonics, 289pp. Springer, Berlin.

Pawley, S. M., Rose, J., Lee, J. R., Hamblin, R. J. O. \& Moorlock, B.S.P. 2004: Middle Pleistocene stratigraphy of Weybourne, north-east Norfolk, England. Proceedings of the Geologists' Association 115, 22-42.

Pawley, S. M., Bailey, R. J. J., Moorlock, B. S. P., Hamblin, R. J. O., Booth, S. J. \& Lee, J. R. 2008: Age limits on Middle Pleistocene glacial sediments from OSL dating, North Norfolk, UK. Quaternary Science Reviews 27, 1365-1377.

Pedersen, S. A. S. 2000: Superimposed deformation in glacitectonics. Bulletin of the Geological Society of Denmark 46, 125-144.

Perrin, R. M. S., Rose, J. \& Davies, H. 1979: The distribution, variation and origins of pre-Devensian tills in eastern England. Philosophical Transactions of the Royal Society of London B287, 535-570.

Phillips, E.R. 2006. Micromorphology of a debris flow deposit: evidence of basal shearing, hydrofracturing, liquefaction and rotational deformation during emplacement. Quaternary Science Reviews 25, 720-738.

Phillips, E. \& Auton, C. A. 2000: Micromorphological analyses of microfabrics and microstructures indicative of deformation processes in glacial sediments. In Maltman, A. J., Hubbard, B. \& Hambrey, J. M. (eds.): Deformation of Glacial Materials, 245-257. Special Publication, Geological Society, London.

Phillips, E. \& Merritt, J. 2008: Evidence for multiple water-escape during rafting of shelly marine sediments at Clava, Inverness-shire, NE Scotland. Quaternary Science Reviews 27, 988-1011.

Phillips, E., Merritt, J., Auton, C.A. \& Golledge, N. 2007: Microstructures in subglacial and proglacial sediments: understanding faults, folds and fabrics and the influence of water on the style of deformation. Quaternary Science Reviews 26, 1499-1528.

Phillips, E., Lee, J. R. \& Burke, H. 2008: Progressive proglacial to subglacial deformation and syntectonic sedimentation at the margins of the Mid-Pleistocene British Ice Sheet: evidence from north Norfolk, UK. Quaternary Science Reviews 27, 1848-1871.

Reade, T. M. 1882: On the Chalk-Masses or Boulders included in the Contorted Drift of Cromer, their Origin and Mode of Transport. Quarterly Journal of the Geological Society of London 28, 222-238. 
Rijsdijk, K. F., Owen, G., Warren, W. P., McCarroll, D. \& van der Meer, J. J. M. 1999: Clastic dykes in over-consolidated tills: Evidence for subglacial hydrofracturing at Killiney Bay, eastern Ireland. Sedimentary Geology 129, 111-126.

Roberts, D. H. \& Hart, J. K., 2005: The deforming bed characteristics of a stratified till assemblage in north East Anglia, UK: investigating controls on sediment rheology and strain signatures. Quaternary Science Reviews 24, 123-140.

Rose, J. \& Allen, P. 1977: Middle Pleistocene stratigraphy in southeast Suffolk. Journal of the Geological Society 133, 83-102.

Rose, J., Moorlock, B.S.P. \& Hamblin, R.J.O. 2001: Pre-Anglian fluvial and coastal deposits in Eastern England: lithostratigraphy and palaeoenvironments. Quaternary International 79, 5-22.

Ruszczynska-Szenajch, H. 1987: The origin of glacial rafts: detachment, transport, deposition. Boreas 16, 101-112.

Slater, G. 1927: The Structure and Disturbed Deposits of Moens Klint, Denmark. Transaction of the Royal Society of Edinburgh 55, 289-302.

Stalker, A. Mac S. 1976: Megablocks, or the enormous erratics of the Albertan Prairies. Geological Survey of Canada, Paper 76-1C, 185-188.

Swiecicki, A. 1980: A foraminferal biostratigraphy of the Campanian and Maastrichtian chalks of the United Kingdom. Unpublished PhD thesis, Plymouth Polytechnic.

van der Meer, J. J. M., Kjaer, K. H., Krüger, J. 1999: Subglacial water escape structures and till structure, Slettjokull, Iceland. Journal of Quaternary Science 14, 191-205.

West, R.G. 1980: The Pre-glacial Pleistocene of the Norfolk and Suffolk Coasts. Xxpp. Cambridge University Press, Cambridge.

Whiteman, C.A. 2002: Implications of a Middle Pleistocene ice-wedge cast at Trimingham, Norfolk, eastern England. Permafrost and Periglacial Processes 13, 163170.

Wilkinson, I. P. 2008: Foraminifera from ice-rafted chalk in northern Norfolk. British Geological Survey Internal Report, 7pp. IR/08/011.

Younger, P. L. 1989: Devensian periglacial influences on the development of spatially variable permeability in the Chalk of southeast England. Quarterly Journal of Engineering Geology and Hydrology 22, 343-354. 


\section{Figures}

Fig. 1. Map of north Norfolk showing the location of the study sites and chalk zones (Lower Campanian - Maastrichtian).

Fig. 2. Lower hemisphere stereographic plot showing structural data obtained from the chalk rafts and adjacent sediments at Overstrand and East Runton (Data for planar structures plotted as dip and dip direction).

Fig. 3. Overview and structural interpretation of a large chalk raft (OV2) exposed in the cliff section at Overstrand.

Fig. 4. Overview and structural interpretation of the thrust zone developed at the base of large chalk raft (OV2) exposed in the cliff section at Overstrand.

Fig. 5. Overview and structural interpretation of part of the cliff section between East Runton and Cromer showing a duplex composed of imbricate thrust-bound slices of chalk bedrock (labelled ER1, ER2 and ER3) and Wroxham Crag Formation. The major thrusts present within the sequence are labelled T1 to T5 (see text for details).

Fig. 6. Overview and structural interpretation of part of the cliff section between East Runton and Cromer showing a structurally higher part of the sequence comprising of imbricate thrust-bound slices of Happisburgh Till Member, chalk bedrock (labelled ER4 and ER5) and Wroxham Crag Formation. The major thrusts present within the sequence are labelled T5 to T7 (see text for details).

Fig. 7. (A) Detailed view of the thrust zone at the base of raft ER2 at East Runton. Note the high strain zone within the underlying Happisburgh Till Member. (B) Original erosive contact between the chalk bedrock and overlying Wroxham Crag Formation preserved within the ice-rafted sediments at East Runton. Note that the gravel lag at the base of the Wroxham Crag Formation is preserved. (C) Detailed view of chalk raft ER2. Note the fracture cleavage and low-angle fractures. (D) Brecciated chalk at East Runton. Note that bedding and jointing are not preserved in this section.

Fig. 8. (A) Deformed lenticular to augen-shaped chalk clasts within the Happisburgh Till Member at East Runton; (B) Detailed view of the glacitectonic foliation developed within the Happisburgh Till Member at East Runton. This fabric wraps around variably rounded, rotated quartz clasts and porphyroclast systems; (C) Deformed base to a raft composed of chalk and Wroxham Crag Formation exposed at in the cliff section between West Runton and Sheringham. The raft is immediately underlain by the highly deformed, locally chalk-rich Happisburgh Till Member; (D) Detailed view of the chalk raft exposed in West Runton cliff exposure, showing a 
narrow shear zone marked by dark grey till cross cutting the chalk raft. Although the chalk is deformed the locally shelly gravel lag at the base of the overlying Wroxham Crag Formation is preserved intact; and (E) Highly deformed chalk within the Happisburgh Till Member exposed at West Runton. The locally chalk-rich foliation within the till is deformed by a shallowly easterly dipping extensional crenulation cleavage.

Fig. 9. Diagram showing the postulated thrust model leading to the detachment of chalk rafts associated with a topographic feature forming an obstruction in front of the advancing ice: (A) Detachment scenario 1, thrusting associated with a palaeocliff line; and (B) Detachment scenario 2, thrusting occurring on the lip of a palaeo-valley.

Fig. 10. (A) Interpretive section summarising the main features associated with the imbricate thrust stack developed at Overstrand; and (B) Interpretive section summarising the main tectonic features associated with the duplex exposed at East Runton.

Fig. 11. Diagram summarising the glaciotectonic model for of chalk raft detachment and emplacement along the north Norfolk coast: (A) Glaciotectonic model for the chalk rafts at Overstrand and East Runton; (B) Initial detachment of chalk rafts associated with a topographical or geological obstacle; (C) Transport and early phase accretion of East Runton chalk rafts (ER1-ER3) as a thrust duplex; (D) Late phase accretion of East Runton chalk rafts (ER4-ER5) by out of sequence thrusting, and the accretion of Overstrand chalk rafts as a thrust duplex. 


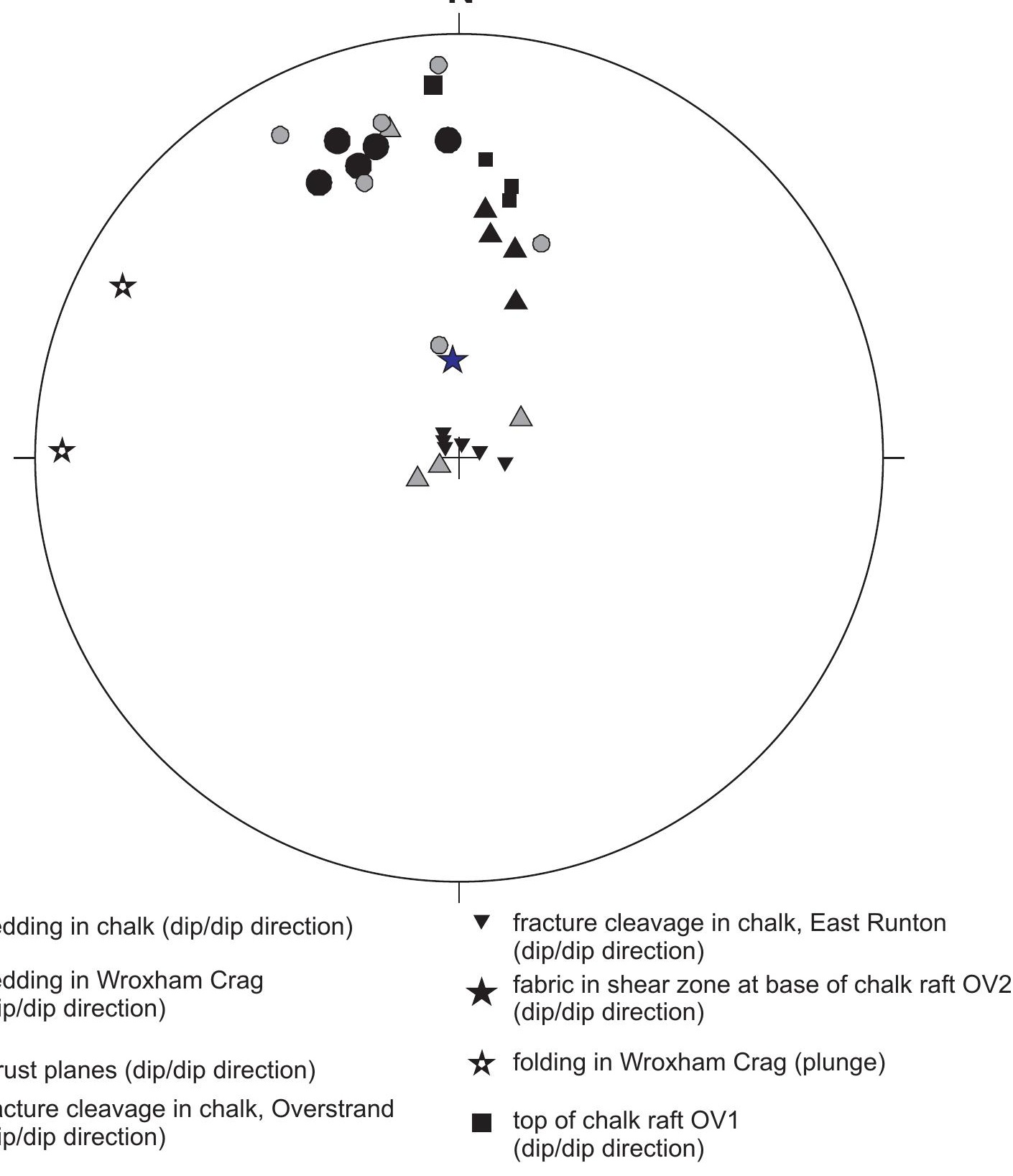

Figure 2 


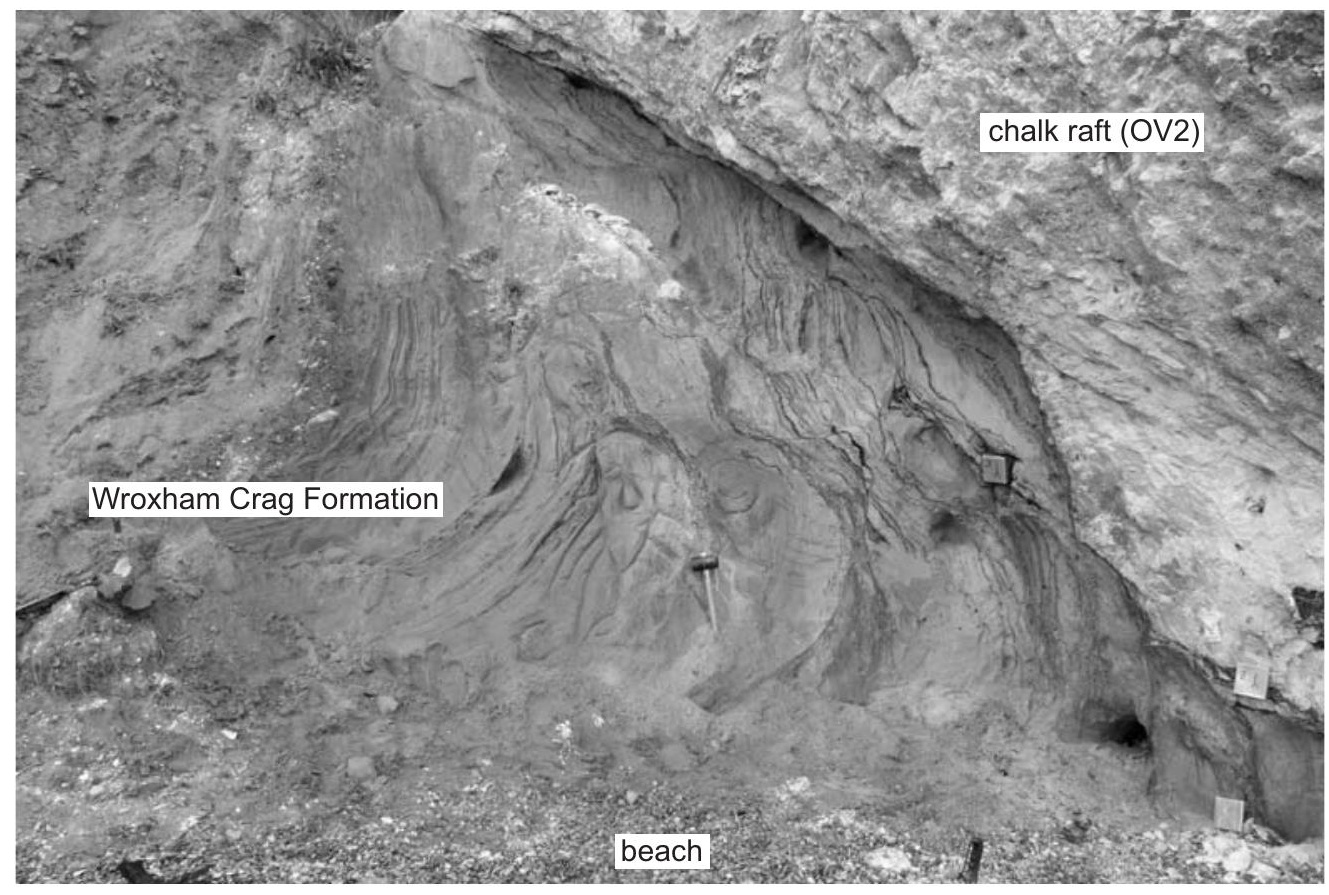

S direction of thrusting and raft emplacement

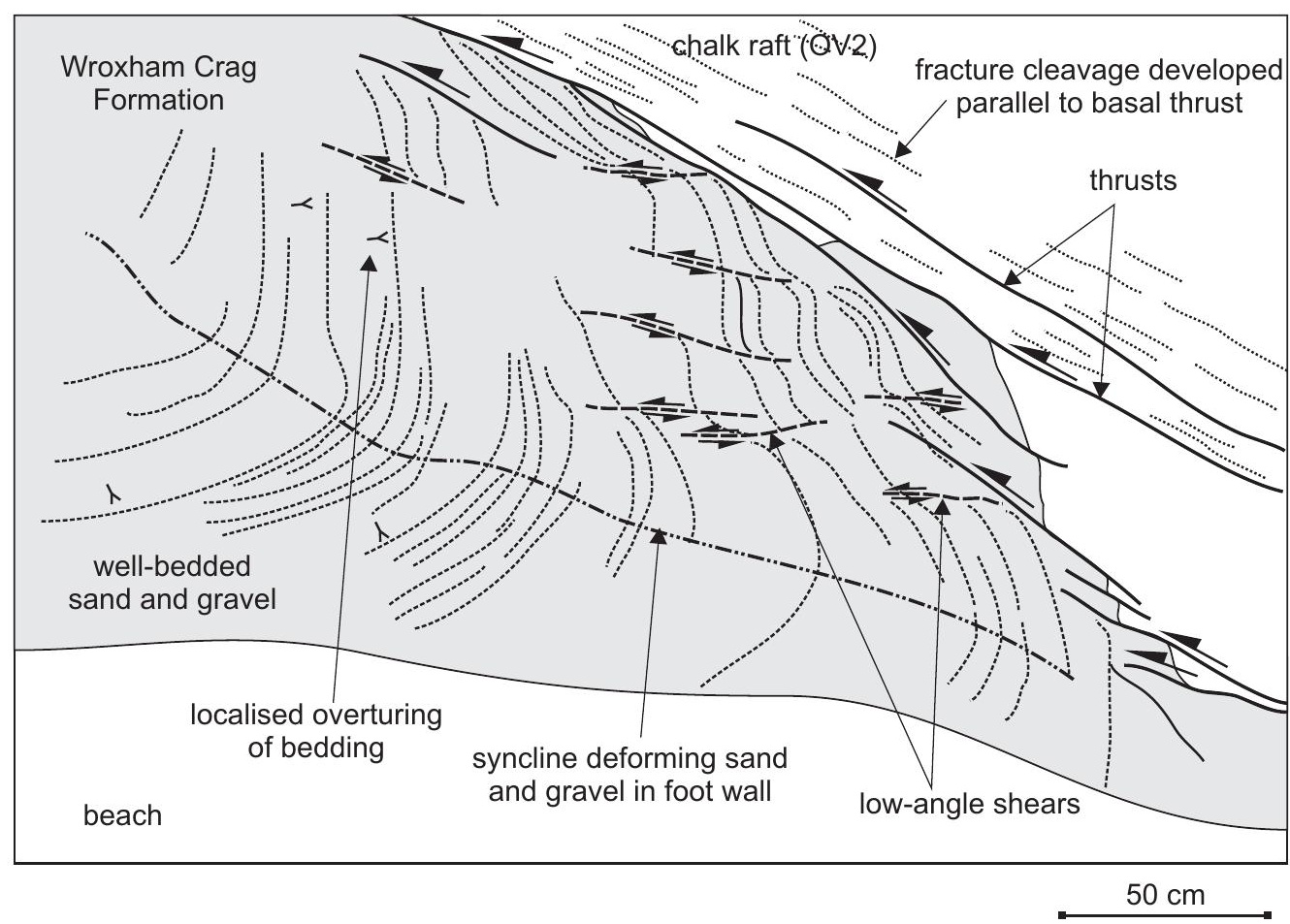

…….... bedding trace of fold axial plane

$\lambda \quad$ way up of sediments

fault/thrust sense of movement on thrusts $=$ sense of movement on shears

Figure 4 


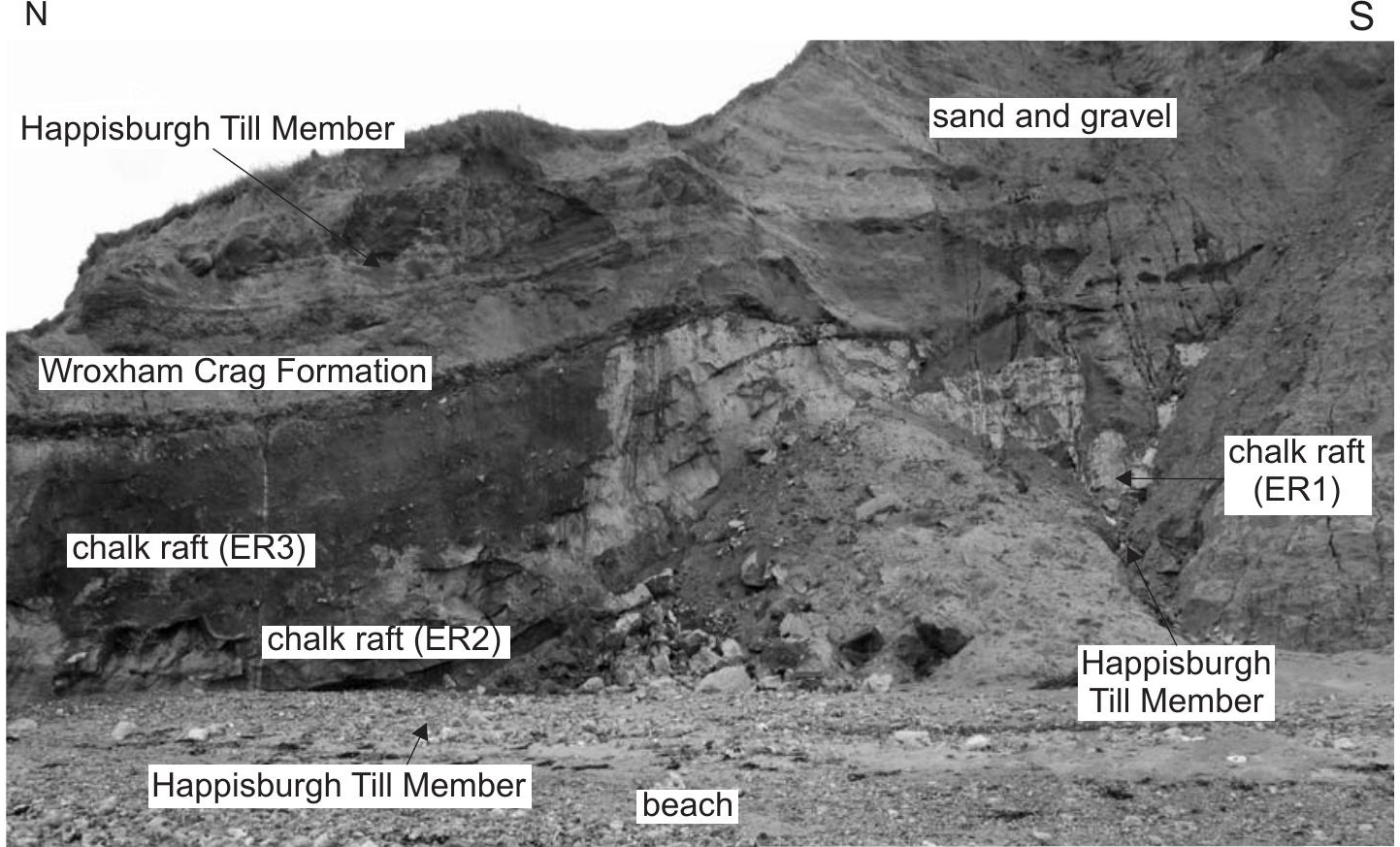

N

direction of thrusting and raft emplacement

Wroxham Crag

Formation

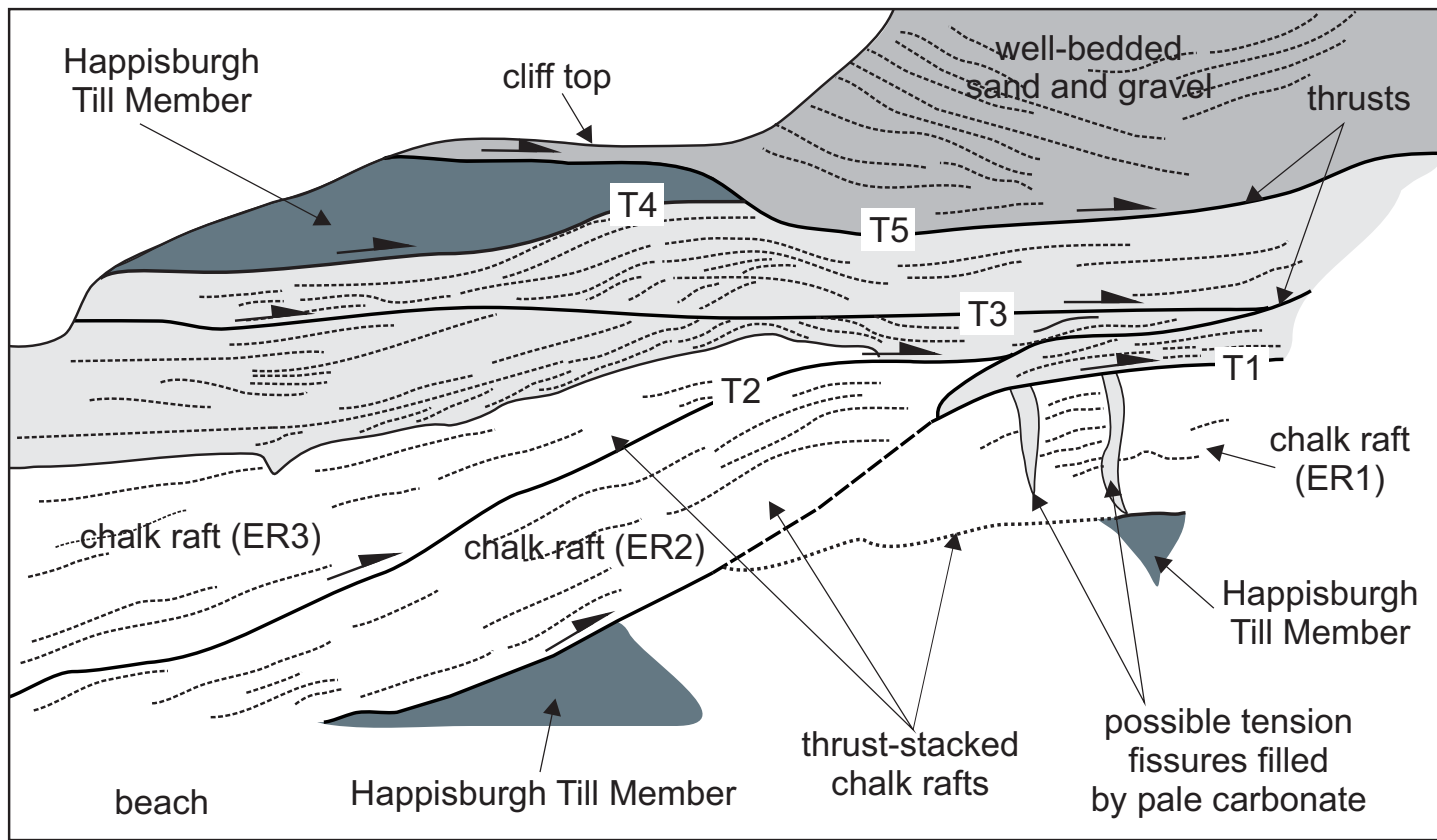

$5 \mathrm{~m}$ 


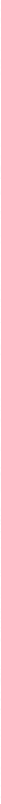

E

direction of thrusting and raft emplacement into cliff face

W

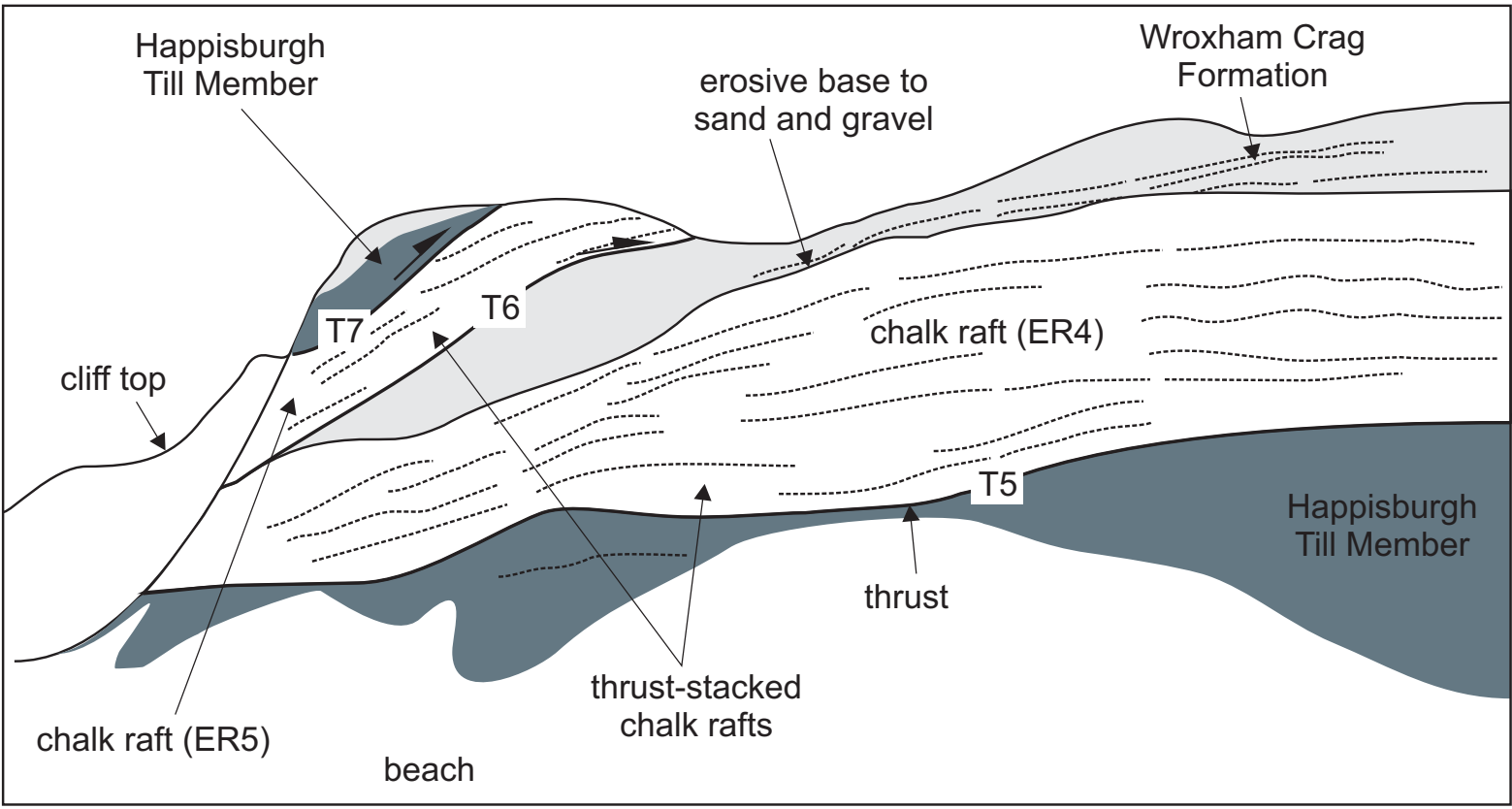

$\cdots$ bedding fault/thrust $>$ sense of movement on thrusts 


\section{A Overstrand}

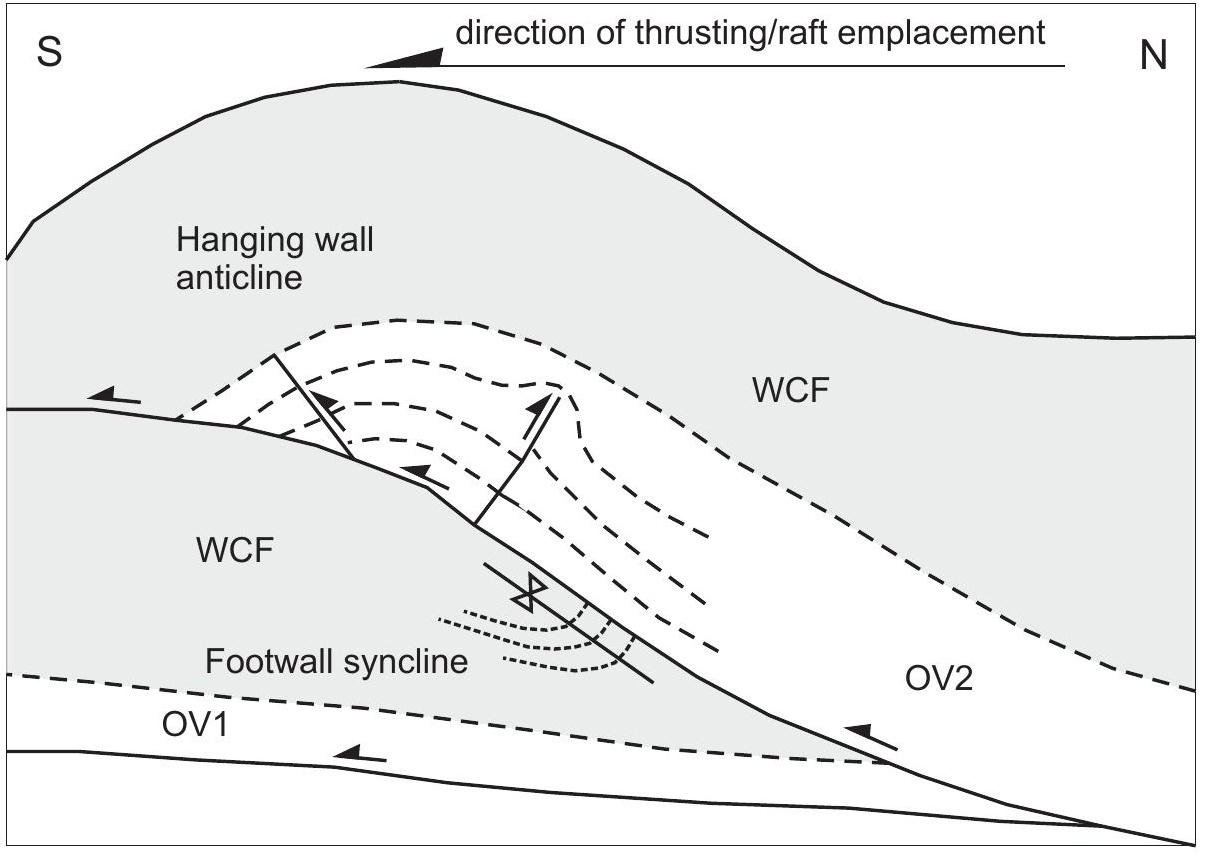

\section{B East Runton}

$S$

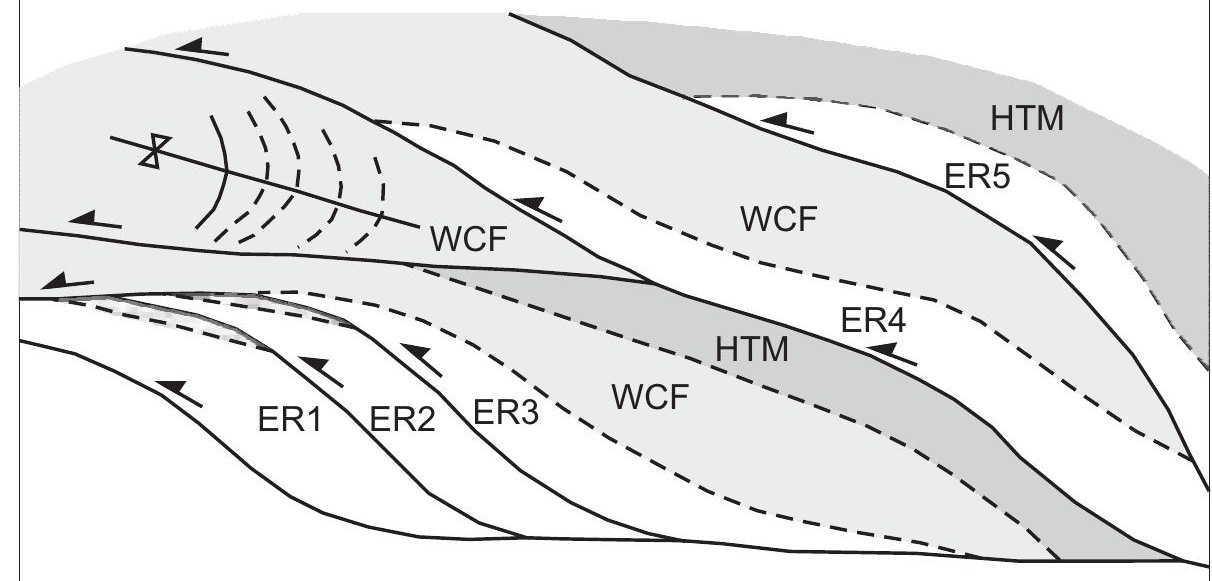


